and had absorbed much of the cerebrum and the upper part of the cerebellum, the outlines of the Arbor Vitae being plainly visible. I have never seen anything like this in any other bird, nor have I seen any account of worms being found parasitic in the brain before.

G. H. FRENCH.

Carbondale, Ill.

\section{Epidemic Forms of Mental or Nervous Diseases or Disorders.}

IN response to the inquiry concerning "epidemic forms of mental or nervous diseases or disorders," in the issue of May 19, I send the following account of an incident which "came to pass" under my own eyes. Several years ago our next-door neighbor's little girl, perhaps five or six years old, met with an accident which rendered it necessary that she use a crutch. Another little girl of about the same age, who lived in the adjoining house, seeing the little lame girl with her crutch, obtained a stick which she used as a crutch, hopping and limping, just as she saw the little lame girl doing. At first no attention was paid to this childish fancy, this imitation, this " playing being lame." After some days had elapsed, however, and this play became so constant as to be annoying, the stick was taken away, and the little girl told to put her foot to the floor. She screamed and cried and insisted most strenuously that she could not put $h \in \mathrm{r}$ foot to the floor: she could not stand upon it, etc. I cannot say how long she persisted in thinking she was lame, but shall never forget how real her apparent affliction was to her, nor her screams of pain when she declared she could not stand without her "crutch"

Columbus, 0 . Mrs. W. A. Kellerman.

\section{The Winter of I7r 9.}

"IN the famous winter of 1709 thousands of families perished in their houses, the Arabic Sea was frozen orer, and even the Mediterranean."

The above is found in a foot-note on page 39 of Professor Meech's article on the intensity of the heat and light of the sun at different latitudes, published in one of the "Smithsonian Contributions to Knowledge." It seems incredible. The "Arabic Sea," I take it, is what we call the Arabian Sea, or at least some one of the bodies of water which border on the Arabian peninsula. No information is given as to where the "thousands of families perished with cold in their houses."

The Arabian Sea measures about 500 miles across its narrowest part. Can it be possible that it was frozen over? or the Red Sea? or the Persian Gulf? or the Gulf of Oman? Has the Mediterranean Sea been frozen over either in historic, or eren in glacial times?

The statement in Professor Meech's paper is made unequivocally, as if speaking of a well-known and well-established fact. It is not put in quotation marks, nor is any authority cited.

A few weeks ago I wrote to Professor Langley, secretary of the Smithsonian, asking for any information which he might be able to give me To-day I received the following reply:-

"I beg to say that I do not know the original source from which his particular statements were derived, but that the winter in question was one of exceptional severity is fully attested by well-authenticated records.

" Under the article 'Temperatur,' in Gehler's 'Physikalisches Wörterbuch,' it is stated that at Paris the thermometer fell many times to $-19^{\circ} \mathrm{C} . ;$ that in the Kleiner Belt of the Danish seas the ice extended so far from the coast that the end of it could not be seen from the highest towers; and that the cold must have been especially intense in southern Germany and Italy, since the Adriatic Sea was wholly covered with ice.

"Additional records of this severe winter will probably be found in the memoirs of $\mathrm{E}$. Brückner, who has been making an extended study of variations in climate."

There is nothing in the fact that at Paris the thermometer fell to $-19^{\circ} \mathrm{C}$., or $31^{\circ}$ below our zero, nor that in the Danish waters ice formed far out from the coast to compare in any way with the freezing over of " the Arabic Sea or the Mediterranean!"

The fact - if it be a fact - that the Adriatic Sea was wholly covered with ice would indeed be very remarkable, but even that was a small affair (indirating a moderate climatic aberration) in comparison with a temperature so abnormally low as to freeze over so large a body as the Mediterrarean, or one so large and so exceptionally warm as the Arabic Sea.

Can any reader of Science, or any one else, throw any light on this subject?

C. B. WARRING.

\section{Animal Effigies.}

CAN you or any of your readers furnish me with a reference or references as to large numbers of small animal effigies of pottery found together in any mound of the United States?

C. B. M.

\section{BOOK-REVIEWS.}

The Moon's Face: A Study of the Origin of its Features. By G. K. GILbert. 52 p. Washington, April, 1893.

THE present paper, although delivered as the presidential address before the Philosophical Society of Washington last December, has only recently been distributed in its complete form. Mr. Gilbert is well known as a geologist and a student of topographic form, and in this paper he has carried his studies away from things terrestrial and turned his eyes and his attention for a time to things celestial. The observations upon which the paper is based were made during three months of the past year. eighteen nights being available for the work, and the $26 \frac{1}{2}$-inch refractor of the U.S. Naval Observatory being the instrument employed. Numerous laboratory experiments were also carrit $d$ on, and the literature relating to lunar topics was searched. The craters, as the most conspicuous features of the moon's face, are mainly dealt with in the paper, and after a description of their characteristics and a statement of the various theories advanced to account for them, the author advances a theory of his own. The volcanic theory is one held by many writers, but a comparison of terrestrial and lunar craters, even when the differences in condition are considered, led Mr. Gilbert to reject the hypothesis as untenable. The "bubble" theory, advocated by Robert Hooke in his Micrographia, in 1667 , is mentioned, but as $\mathrm{Mr}$. Gilbert had not seen the book the theory is not discussed in any detail. It may not be amiss to devote a few words to it here.

Hooke describes the features of the craters as he saw them through his telescope, and gives an illustıation of some of them. Except as regards detail and the characteristic central hill shown in Mr. Gilbert's figures, those giren by Hooke are very similar. In describing the craters he says: "These seem to me to have been the effects of some motions within the body of the moon, analogous to our earthquakes, by the eruption of which, as it has thrown up a brim or ridge round about higher than the ambient surface of the moon, so has it left a hole or depression in the middle, proportionally lower." He also mentions, what is of more interest, that he had made several experiments to ascertain, if possible, the origin of the pits. "The first was with a very soft and well-tempered mixture of tobacco-pipe clay and water, into which, if I let fall any heavy body. as a bullet, it would throw up a mixture round the place, which for a while would make a representation not unlike these of the moon, but considering the state and condition of the moon, there seems not any probability to imagine that it should proceed from any cause analogous to this; for it would be difficult to imagine whence those bodies should come; and next, how the substance of the moon should be so soft; but if a bubble be blown under the surface of it, and suffered to rise and break; or if a bullet or other body sunk in it be pulled out from it, these departing bodies leave an impression on the surface of the mixture exactly like those of the moon, save that these also quickly subside and vanish. But the second and most notable representation was what $I$ observed in a pot of boiling alabaster, for then that powder being by the eruption of vapors reduced to a kind of fluid consistence, if, whilst it boils, it be gently remored beside the fire, the alabaster presently ceasing to boil, the whole surface, especially that where some of the last bubbles have risen, will appear all over covered with small pits exactly shaped like these of the moon, and by holding a lighted 